\begin{tabular}{|c|c|c|c|c|}
\hline SHARE: SOCIAL WORK JURNAL & VOLUME: 6 & NOMOR: 1 & HALAMAN: 1 -- 153 & $\begin{array}{r}\text { ISSN:2339-0042 } \\
\text { ISSN: } 2528-1577 \text { (elektronik) }\end{array}$ \\
\hline
\end{tabular}

\title{
SERTIFIKASI MENEGASKAN EKSISTENSI PEKERJA SOSIAL DI INDONESIA
}

Oleh:

\author{
Rudi Saprudin Darwis ${ }^{1}$
}

Email:

1 Ketua Lembaga Sertifikasi Profesi Pekerjaan Sosial Indonesia

\begin{abstract}
ABSTRAK
Eksistensi pekerjaan sosial sebagai profesi mengalami perkembangan sejak diterbitkannya UU No 11 Tahun 2009. Salah satu amanat dari dari undang-undang tersebut adalah pelaksanaan sertifikasi bagi pekerja sosial profesional dan tenaga kesejahteraan sosial sebagai sumberdaya manusia kesejahteraan sosial. Tulisan ini menjelaskan bagaimana pelaksanaan sertifikasi pekerja sosial di indonesia berdasarkan Permensos RI Nomor 03 Tahun 2015 serta konsekuensi dari sertifikasi tersebut bagi penguatan eksistensi profesi pekerjaan sosial di Indonesia.
\end{abstract}

Kata kunci: sertifikasi, pekerja sosial, eksistensi profesi

\section{A. Pengantar}

Pekerjaan sosial di Indonesia hingga saat ini masih menghadapi tantangan dalam hal eksistensinya sebagai sebuah profesi. Pekerjaan sosial dituntut untuk mampu menunjukkkan bentuk kiprah yang secara spesifik dapat dinilai oleh masyarakat luas sebagai aktivitas yang dapat dibedakan dari profesi atau tenaga ahli lainnya secara signifikan. Aktivitas pelayanan kesejahteraan sosial yang dilakukan oleh pekerja sosial (profesional) harus nampak secara nyata berbeda dengan pelayanan yang dilakukan oleh mereka yang bukan pekerja sosial. Pekerja sosial melakukan pekerjaannya dengan berdasarkan kepada pengetahuan (teori dan konsep) dengan menggunakan teknikteknik (keterampilan) yang dikuasainya dan berlandasan kepada nilai-nilai (etika) profesionalnya.

Masih banyak hal yang harus dibenahi oleh stakeholders dalam bidang pekerjaan 
sosial untuk mendapatkan pengakuan dari masyarakat. Pengakuan yang dimaksud adalah adanya kebutuhan dari masyarakat secara nyata terhadap pekerja sosial sebagai sebuah profesi untuk berkiprah dalam proses pembangunan. Bagaimanapun juga, pengakuan terhadap eksistensi pekerjaan sosial tidak dapat diminta dari masyarakat begitu saja, melainkan hanya akan dapat diberikan ketika para pekerja sosial dapat menunjukkan karya nyata yang dirasakan manfaatnya oleh masyarakat. Terlebih lagi ketika masyarakat merasakan bahwa pelayanan sosial yang diberikan oleh pekerja sosial dapat memberikan hasil yang lebih baik.

Permasalahan mengenai eksistensi pekerjaan sosial di Indonesia tidak terlepas dari kenyataan yang ada bahwa pelaku-pelaku pelayanan kesejahteraan sosial tidak hanya mereka yang berpendidikan pekerjaan sosial/kesejahteraan sosial melainkan juga mereka yang berlatar belakang pendidikan lainnya. Bahkan, mereka yang tidak berpendidikan tinggi pun dapat melakukannya ketika mereka perlu/ingin membantu orang lain; mereka sesungguhnya adalah para volunteer.

Bagi masyarakat pada umumnya, tidak ada bedanya antara pekerja sosial (profesional) dengan volunteer, mereka dikategorikan

\footnotetext{
${ }^{4}$ Peraturan Menteri Sosial nomor 03 Tahun 2015 tentang Sertifikasi Pekerja Sosial Profesional merupakan revisi terhadap Peraturan Menteri Sosial
}

sebagai "pekerja sosial", yaitu orang-orang yang bekerja membantu orang yang mengalami kesulitan hidup karena berbagai sebab secara sukarela. Hal ini telah menimbulkan dampak yang kurang menguntungkan bagi pekerjaan sosial sebagai sebuah profesi; terlebih lagi jika pelayanan yang diberikan tidak dapat memberikan hasil yang memuaskan atau menimbulkan dampak yang tidak diharapkan. Dalam situasi demikian, sulit untuk memberikan jaminan bahwa pelayanan yang diperoleh masyarakat merupakan pelayanan yang baik dan masyarakat (penerima pelayanan) seolah-olah tidak memiliki hak untuk menuntut pelayanan yang seharusnya. Pekerjaan sosial telah dianggap sebagai pekerjaan yang dapat dilakukan oleh siapapun dengan bermodalkan 'niat baik' saja.

Pemberian pelayanan yang baik dari seorang pekerja sosial akan memberikan dampak yang baik terhadap eksistensi pekerjaan sosial sebagai sebuah profesi. Untuk itu, harus dipastikan bahwa pekerja sosial yang melakukan pelayanan memiliki kualifikasi yang baik dan sesuai dengan tuntutan kualitas pelayanan yang baik; caranya dengan melalui sertifikasi. Seperti tercantum dalam Permensos No. 03 Tahun $2015^{4}$ bahwa "Sertifikasi adalah proses pemberian sertifikat kepada Pekerja 
Sosial setelah lulus uji kompetensi". Kepentingan lainnya adalah seperti yang tercantum dalam Permensos No. 03 Tahun 2015 bahwa sertifikasi bertujuan untuk :
a. memberikan pengakuan atas kualifikasi dan kompetensi Pekerja Sosial;
b. meningkatkan tanggung jawab Pekerja Sosial;
c. memberikan kepastian hukum dalam praktik profesional bagi Pekerja Sosial;dan

d. melindungi masyarakat untuk memperoleh pelayanan kesejahteraan sosial yang berkualitas.

\section{B. Kelembagaan Sertifikasi Pekerja Sosial}

Sertifikasi pekerja sosial di Indonesia dimulai dengan adanya amanat Pasal 53 Undang-Undang Nomor 11 Tahun 2009 tentang Kesejahteraan Sosial untuk menerbitkan Peraturan Menteri Sosial RI mengenai sertifikasi pekerja sosial profesional dan tenaga kesejahteraan sosial. Karena itulah pada Tahun 2009 diterbitkan Peraturan Menteri Sosial Republik Indonesia Nomor 108/HUK/2009 Tentang Sertifikasi Bagi Pekerja Sosial Profesional Dan Tenaga Kesejahteraan Sosial. Namun Permensos Nomor 108/HUK/2009 ini direvisi sebanyak dua kali dengan diterbitkannya Peraturan Menteri Sosial Republik Indonesia Nomor 16/HUK/2012 Tentang Sertifikasi Pekerja Sosial Profesional Dan Tenaga Kesejahteraan
Sosial serta Peraturan Menteri Sosial Republik Indonesia Nomor 03 Tahun 2015 Tentang Sertifikasi Pekerja Sosial Profesional.

Sebagai konsekuensi dari penerbitan Permensos RI tentang Sertifikasi Pekerja Sosial dan Tenaga Kesejahteraan Sosial, maka pada Tahun 2010 dibentuklah Lembaga Sertifikasi Pekerjaan Sosial (LSPS) yang tugas utamanya melakukan sertifikasi terhadap Pekerja Sosial Profesional dan Tenaga Kesejahteraan Sosial (TKS). Namun dengan terbitnya Permensos RI No. 03 Tahun 2015 maka tugas LSPS hanya melakukan sertifikasi terhadap Pekerja Sosial Profesional saja. LSPS merupakan lembaga independen yang berwenang memberikan penilaian untuk menentukan kualifikasi dan kompetensi yang sesuai di bidang penyelenggaraan kesejahteraan sosial. LSPS berisi orang-orang yang berasal dari pilar-pilar pekerjaan sosial di Indonesia, yaitu asosisasi profesi (Ikatan Pekerja Sosial Profesional Indonesia), asosiasi pendidikan (Ikatan Pendidikan Pekerjaan Sosial/Kesejahteraan Sosial Indonesia), dan Dewan Nasional Indonesia Untuk Kesejahteraan Sosial (DNIKS). Untuk mendukung operasionalisasi kegiatan LSPS, sekretaris LSPS dijabat oleh kepala unit kerja kementerian sosial yang membidangi sertifikasi, yaitu Kepala Pusat Pengembangan Profesi Pekerja Sosial dan Penyuluh Sosial Kementerian Sosial RI.

Secara kelembagaan, meskipun personil LSPS berasal dari pilar-pilar 
pekerjaan sosial di Indonesia, tidak berarti LSPS ini tidak memiliki kemandirian. Secara kelembagaan LSPS sesungguhnya mandiri dalam melakukan berbagai kegiatannnya, serta dalam pengambilan keputusan yang berkaitan dengan proses dan hasil uji komptensi untuk sertifikasi. Dalam membangun sistem sertifikasi, selama ini LSPS berhasil membangun sinergi dengan pilar-pilar pekerjaan sosial, terlebih lagi LSPS selaku lembaga penyelenggara sertifikasi pada dasarnya menggunakan beberapa instrumen yang penetapannya tidak berada di wilayah kewengan LSPS, seperti Standard Kompetensi yang dirumuskan bersama diantara pilar pekerjaan sosial dan ditetapkan oleh Menteri Sosial RI.

Meskipun secara substansi dan mekanisme sertifikasi LSPS memiliki independensi yang luas, namun secara finansial LSPS anggaran kegiatan LSPS sepenuhnya masih dibiayai oleh Kementerian Sosial RI melalui Pusat Pengembangan Profesi Pekerjaan Sosial dan Penyuluhan Sosial. Sebagai konsekuensinya, LSPS harus menyesuaikan dengan kondisi anggaran di kementerian sosial. Namun hal ini sangat berarti karena dapat menjaga keberlangsungan proses sertifikasi pekerja sosial di Indonesia yang kondisinya masih dalam proses menetapkan eksistensinya. Sampai saat ini, LSPS tidak melakukan pungutan bagi peserta uji kompetensi. Meskipun demikian, dalam jangka panjang LSPS harus dapat membiayai sendiri kegiatan sertifikasi.

\section{Sasaran Sertifikasi}

Berdasarkan amanat Permensos No. 03 Tahun 2015, LSPS menyelenggarakan sertifikasi bagi Pekerja Sosial Profesional. Meskipun dalam UU No 11/2009 dinyatakan bahwa pelaku pelayanan kesejahteraan sosial di Indonesia adalah pekerja sosial profesional dan TKS dan harus dilakukan sertifikasi terhadap mereka, namun sertikasi bagi Tenaga Kesejahteraan Sosial tidak dilakukan oleh LSP melainkan oleh lembaga sertifikasi TKS. Sebagaimana yang tercantum dalam UU No. $11 / 2009$, adapun yang dimaksud dengan:

a. Pekerja Sosial Profesional yang selanjutnya disebut pekerja sosial adalah seseorang yang bekerja, baik di lembaga pemerintah maupun swasta yang memiliki kompetensi dan profesi pekerjaan sosial, dan kepedulian dalam pekerjaan sosial yang diperoleh melalui pendidikan, pelatihan dan/atau pengalaman praktik pekerjaan sosial untuk melaksanakan tugas-tugas pelayanan dan penanganan masalah sosial;

b. Tenaga Kesejahteraan Sosial yang selanjutnya disebut TKS adalah seseorang yang dididik dan dilatih secara profesional untuk 
melaksanakan tugas-tugas pelayanan dan penanganan masalah sosial dan/atau seseorang yang bekerja, baik di lembaga pemerintah maupun swasta yang ruang lingkup kegiatannya di bidang kesejahteraan sosial.

Bila memperhatikan kedua definisi di atas, maka terdapat keganjilan dalam pengertian tersebut, yaitu TKS nampak lebih profesional dibandingkan dengan Pekerja Sosial Profesional. Sebenarnya yang dimaksud dengan TKS adalah mereka yang selama ini terlibat dalam penyelenggaraan pelayanan kesejahteraan sosial namun berlatar belakang pendidikan bukan pekerjaan sosial/kesejhteraan sosial. Hal ini nampak pada Pasal 13 sampai Pasal 15 Permensos No. 16/2012 untuk persyaratan pendidikan bagi TKS yang mengikuti sertifikasi TKS, yaitu pendidikan non pekerjaan sosial/kesejahteraan sosial. Mereka ini terdiri dari berbagai latar belakang pendidikan, yang beberapa diantaranya telah memiliki lembaga sertifikasi sendiri, seperti psikologi, akuntansi, dan kedokteran. Hal ini pula lah yang menjadi salah satu dasar pertimbangan bagi LSPS untuk tidak melakukan sertifikasi bagi para TKS. Kondisi ini menuntut LSPS untuk memikirkan kembali sistem sertifikasi yang akan diberlakukan terhadap TKS, dengan memperhatikan keberadaan lembaga sertifikasi untuk profesi dan bidang keahlian lain. Yang harus jadi perhatian, jangan sampai terjadi standar kompetensi yang digunakan utnuk uji kompetensi antara pekerja sosial dengan TKS adalah sama.

Hal lain yang juga menjadi perhatian adalah tidak dapat dipungkiri bahwa banyak diantara para TKS yang memiliki kemampuan praktik yang sangat baik sebagai hasil dari pengalaman penanganan klien selama ini seperti yang dilakukan oleh pekerja sosial, namun tidak dapat disertifikasi sebagai pekerja sosial karena latar belakang pendidikan yang tidak memenuhi ketentuan yang berlaku. Keberadaan mereka tidak terlepas dari kebijakan mengenai pengadaan sumberdaya manusia untuk pelayanan kesejahteraan sosial yang diberlakukan oleh Kementerian Sosial dan lembaga pelayanan sosial milik masyarakat selama ini.

\section{Jenjang Sertifikasi Pekerja Sosial}

Sertifikasi pekerja sosial dilakukan dengan memperhatikan jenjang keahlian Pekerja Sosial. Adapun jenjang keahlian yang dijadikan dasar dalam melakukan sertifikasi berdasarkan Permensos No. 03 Tahun 2015 adalah pekerja sosial generalis, yaitu untuk jenjang yang berpendidikan sarjana. Dalam kenyataannnya, sumberdaya yang terlibat dalam penyelenggaraan pelayanan kesejahteraan sosial ada pula yang berasal dari jenjang pendidikan di bawah sarjana yang selanjutnya akan menjadi Asisten Pekerja Sosial serta Pekerja Sosial Spesialis bagi yang berpendidikan pascasarjana. Untuk jenjang 
asisten, dia tidak dikategorikan sebagai pekerja sosial profesional, sedangkan jenjang generalis dan spesialis termasuk kategori profesional. Untuk kategori profesional, diberlakukan bahwa jenjang generalis menjadi syarat untuk mendapatkan sertifikat sebagai pekerja sosial spesialis.

Ambigu terjadi dalam kategorisasi ini antara generalis dan spesialis, karena istilah generalis yang merupakan pencapaian pembelajaran pada jenjang sarjana digunakan sebagai tingkat kompetensi seorang pekerja sosial. Istilah ini sesunguhnya untuk menunjukan bahwa seorang sarjana pekerjaan sosial tingkat kemampuan dan kewenangannya dalam menangani permasalahan dalam batas tertentu. Sedangkan jenjang spesialis tidak sekedar menunjukkan kekhususan bidang pelayanan, karena pada umumnya seorang sarjana pekerja sosial akan sudah mengkhususkan diri pada bidang praktik, namun jenjang spesialis ini menunjukkan tingkatan yang lebih ahli (advance). Adanya prasyarat pendidikan yang menyertai penjenjangan ini untuk menegaskan menjadi seorang spesialis memrlukan proses pendalaman praktik dengan disertai pengayaan wawasan dan tanggung jawab melalui proses pendidikan formal. Terlebih lagi penjenjangan ini selanjutnya akan diikuti dengan pemberian kewenangan yang berbeda. Perbedaan kemampuan praktik dan kewenganan dari setiap jenjang akan nampak dalam standard kompetensi yang digunakan dalam uji kompentensi.

\section{E. Standard Kompetensi dan Uji Kompetensi Pekerja Sosial}

Standard kompetensi yang digunakan dalam uji kompetensi disusun bersama pilarpilar pekerjaan sosial di Indonesia, walaupun standar kompetensi tersebut belum disepakati secara formal melalui sebuah konvensi nasional. Namun, standard kompetensi yang dirumuskan telah disepakati dan dapat digunakan sebagai acuan dalam melakukan uji kompetensi untuk sertifikasi. Standard komptetensi merupakan ukuran kemampuan yang meliputi pengetahuan, keterampilan, dan nilai pekerjaan sosial dalam praktik pekerjaan sosial. Standard kompetensi dirumuskan dengan mengacu kepada:

a. Kerangka Kualifikasi Nasional Indonesai (KKNI) untuk Ilmu Kesejahteraan Sosial; Level 6 untuk S1/DIV dan Level 8 untuk S2/Spesialis,

b. Kompetensi Utama pendidikan pekerjaan sosial yang digunakan oleh IPPSI,

c. Standar Praktik yang dirumuskan oleh asosiasi profesi

d. Hasil Kajian (Penelitian/Literatur/Benchmarkin g) yang dilakukan oleh asosiasi pendidikan maupaun asosiasi profesi 
Hasil kajian dan Benchmarking memberikan pembelajaran yang berarti dalam membangun sistem sertifikasi pekerja sosial maupun lisensi. Beberapa sistem sertifikasi dari berbagai negara maupun dari profesi lain dijadikan pembanding, termasuk yang dijadikan pembading dalam menentuak bentuk uji kompetensi yang sesuai dengan karakteristik pekerjaan sosial sebagai sebuah profesi.

Sebagai salah satu profesi yang bergerak di bidang pemberian bantuan (helping profession), uji kompetensi yang dilakukan terhadap pekerja sosial harus mampu memberikan gambaran kemampuan pada aspek pengetahuan, keterampilan, dan terutama aspek nilai. Kualifikasi seorang pekerja sosial akan tercermin terutama ketika menggunakan kerangka nilai yang dimilikinya dalam menggunakan pengetahuan dan keterampilan ketika menangani klien. Oleh karena itu, mekanisme pengujian dalam sertifikasi ini LSPS membuat instrumen pengujian dalam bentuk portofolio dan ujian tertulis yang tidak hanya memberikan informasi kepada tim penilai (asesor) mengenai pengetahuan peserta uji kompetensi. Kemampuan praktik diharapkan akan tercermin dalam deskripsi diri yang dibuat oleh peserta pada saat membuat portofolio. Track reccord peserta dalam melakukan praktik akan dikonfirmasi dengan Daftar Riwayat Hidup peserta beserta bukti-bukti fisiknya seperti surat keputusan, sertifikat, dan lain-lain. Portofolio tersebut dilengkapi pula dengan penilaian persepsional dari klien/penerima manfaat terhadap yang besangkutan. Penilaian ini akan mencerminkan perilaku dan kemampuan pekerja sosial pada saat melakukan pemberian pelayanan kepada klien/penerima manfaat. Naskah Ujian Tulis disiapkan oleh tim khusus yang mengolah soal ujian tulis agar dapat memenuhi standar kompetensi yang diujikan..

\section{F. Prosedur Sertifikasi}

Uji kompetensi dengan menggunakan instrumen portofolio dan ujian tulis diberlakukan pada uji kompetensi $\underline{\text { Jalur }}$ Penilaian Langsung, yaitu untuk pekerja sosial generalis yang berpengalaman lebih dari 3 tahun. Sedangkan untuk yang berpengalaman 20 tahun atau lebih dan berusia sekurangkurangnya 45 tahun dapat mengikuti uji kompetensi Jalur Sertifikasi Langsung, yaitu uji kometensi dengan hanya menggunakan Portofolio instrumen penilaiannya. Adapun untuk Jalur Pelatihan Sertifikasi tidak diberlakukan kepada pekerja sosial.

\section{Untuk Jalur Pendidikan Profesi,} sertifikasi dilakukan secara terintegrasi bersama sistem pendidikan yang diselenggarakan di perguruan tinggi, sehingga pemberian sertifikat dapat diberikan seiring dengan selesainya pendidikan profesi. Kebijakan Kementerian Pendidikan bahwa 


\begin{tabular}{|c|c|c|c|c|}
\hline SHARE: SOCIAL WORK JURNAL & VOLUME: 6 & NOMOR: 1 & HALAMAN: 1 -- 153 & ISSN:2339-0042 (cetak) \\
\hline
\end{tabular}

pedidikan profesi diselenggarakan setelah pendidikan sarjana. Sampai saat ini belum ada perguruan tinggi di Indonesia yang menyelenggarakan pendidikan profesi. Hal ini menjadi catatan tersendiri bagi asosiasi pendidikan untuk mulai merintis penyelenggaraan pendidikan profesi pekerjaan sosial. Penyelenggaraan pendidikan profesi pekerjaan sosial nampaknya akan menjadi pendorong untuk adanya pengakuan pekerjaan sosial sebagai salah satu profesi pemberian bantuan.

Secara skematis, prosedur sertifikasi pekerja sosial di Indonesia dapat digambarkan pada Bagan 1 berikut:

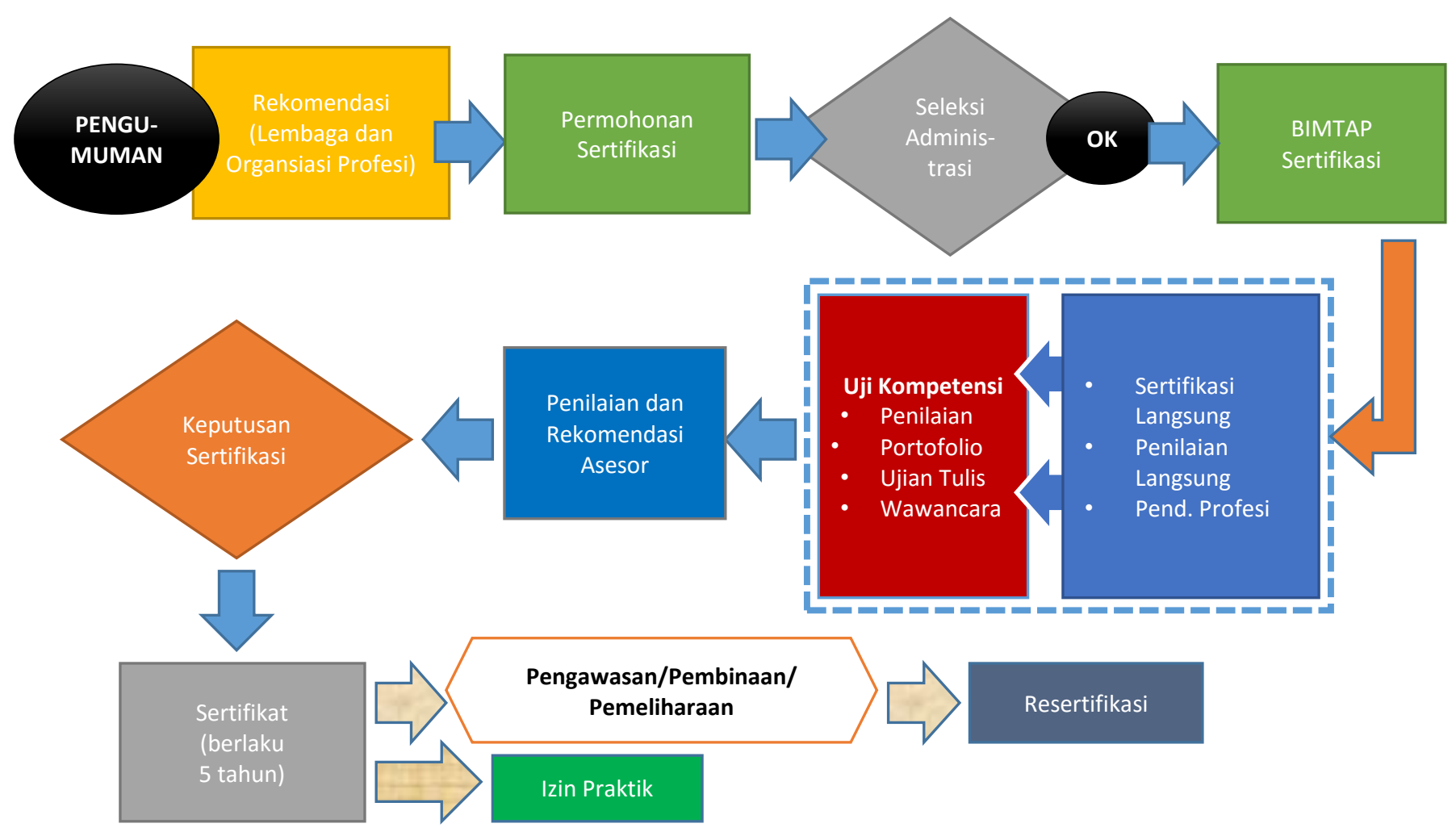

Bagan 1 Prosedur Sertifikasi Pekerja Sosial di Indonesia

Sumber: diolah dari Peraturan Menteri Sosial RI No. 03 Tahun 2015

Sertifikasi terhadap pekerja sosial merupakan hak bagi pekerja sosial untuk dapat memperoleh pengakuan sebagai pekerja sosial profesional. Oleh karena itu, setiap pekerja sosial dapat mengajukan diri untuk mendapatkan sertifikat setelah mengikuti uji kompetensi sesuai dengan jalur sertifikasi yang ditempuhnya. Jika memenuhi kriteria kelulusan yang ditetapkan, maka seorang pekerja sosial akan mendapatkan sertifikat pekerja sosial profesional sesuai dengan jenjang sertifikasi, yang berlaku selama 5 tahun. Untuk memperpanjangnya, sertifikat 
kompetensi ini akan terkait dengan kepemilikan Lisensi (Ijin Praktik).

\section{G. Lisensi (Ijin Praktik) Pekerja Sosial di}

\section{Indonesia}

Sertifikasi diberikan kepada seorang pekerja sosial sebagai bentuk pengakuan terhadap kualifikasi yang dimiliki oleh pekerja sosial. Dengan pengakuan terhadap kualifikasi yang dimilikinya, seorang pekerja sosial akan dapat mengajukan ijin praktik sebagai pekerja sosial kepada negara melalui Kementerian Sosial. Ijin praktik diberikan kepada pekerja sosial secara perorangan. Dengan memiliki ijin praktik, maka seorang pekerja sosial memiliki kewenangan untuk menjalankan perannya sebagai pekerja sosial. Ijin praktik yang diterbitkan untuk seorang pekerja sosial menunjukkan adanya mandat dari negara kepada dirinya untuk melakukan praktik pekerjaan sosial.

Dalam proses penerbitan ijin praktik, Permensos nomor 03 Tahun 2015 mengamanatkan bahwa pekerja sosial dapat mengajukan ijin praktik kepada Menteri Sosial melalui LSPS. Komponen penting yang harus dipenui dalam pengajuan ijin praktik ini adalah rekomendasi dari asosiasi profesi. Hal ini mengingat bahwa pembinaan dan pengawasan terhadap pekerja sosial yang memiliki sertifikasi kompetensi maupun ijin praktik dilakukan oleh asosiasi profesi. Pembinaan dan pengawasan ini sangat diperlukan pekerja sosial untuk memastikan bahwa praktik yang dilakukan berjalan dengan benar dan mencapai kualitas pelayanan yang diharapkan.

\section{H. Implikasi Sertifikasi Pekerja Sosial di Indonesia}

Upaya penjaminan kualifikasi pekerja sosial menimbulkan beberapa implikasi yang mencakup beberapa hal, antara lain:

a. Standardisasi Pendidikan

Pekerjaan Sosial. Standardisasi dalam pengujian kompetensi untuk sertifikasi, menuntut dilakukannya standardisasi dalam pendidikan pekerjaan sosial, terutama mengenai kurikulum pendidikan pekerjaan sosial/kesejahteraan sosial di Indonesia. Dalam hal ini, peranan IPPSI sebagai asosiasi pendidikan pekerjaan sosial sangat menentukan. Peran selanjutnya terkait dengan keberadaan IPPSI adalah mendorong dan menyiapkan perangkat penyelenggaraan pendidikan profesi pekerjaan sosial.

b. Penempatan sumberdaya manusia dalam bidang kesejahteraan sosial. Dengan sertifikasi, kualifikasi dan kompetensi seseorang yang berkecimpung dalam bidang pelayanan kesejahteraan sosial akan dapat ditentukan dengan jelas. Untuk itu, perlu dilakukan 
penataan mengenai pihak-pihak yang menjadi pelaku utama dalam pelayanan kesejahteraan sosial dan sebagai pelaku pendukung pelayanan kesejahteraan sosial.

c. Pengembangan dan pemeliharaan. Proses sertifikasi bukanlah sebagai proses akhir dalam rangkaian pengelolaan sumberdaya manusia dalam pelayanan kesejahteraan sosial. Untuk menjaga dan meningkatkan kualitas pekerja sosial dalam pelayanan, perlu dibangun sistem pengembangan dan pemeliharaan pekerja sosial. Hal ini secara langsung akan terkait dengan rangkaian dari sertifikasi pekerjaan sosial, yaitu tahap Resertifikasi.

d. Penataan SDM di Lembagalembaga Kesejahteraan Sosial. Pada lembaga kesejahteraan sosial akan perlu diatur mengenai hirarkhie dan rentang kendali para personalia lembaga, baik pada bidang manajerial kelembagaan maupun dalam pelaksanaan pelayanan kepada penerima manfaatnya. Denan sertifikasi, kualifikasi dan kompetensi pekerja sosial dapat dipetakan dan diatur pemberian kewenangan beserta ikutannya diantara sumberdaya manusia lembaga. e. Pelindungan dan pengawasan. Aspek penting dari sertifikasi adalah pengakuan terhadap kualifikasi yang dimiliki oleh seseorang, sehingga dengan kualifikasi yang dimilikinya seseorang akan mendapatkan kewenangan tertentu dalam pelayanan kesejahteraan sosial. Kejelasan dalam pemberian kewenangan kepada pekerja sosial akan memberikan akses yang lebih luas kepada pekerja sosial dalam melakukan praktik pekerjaan sosialnya. Oleh karena itu, perlu dibangun sistem perlindungan agar pekerja sosial dapat menjalankan tugasnya sesuai dengan kewenangannya. Selain itu, untuk memastikan pekerja sosial menjalankan tugas berdasarkan kewenangannya dengan tanpa melakukan penyimpangan atau melebihi kewenangannya, perlu dibuat mekanisme pengawasan terhadap praktik pekerja sosial. Terlebih lagi dengan akan semakin terbukanya kesempatan bagi pekerja sosial untuk melakukan praktik mandiri.

\section{Penutup}

Hal strategis yang sedang dilakukan oleh LSPS adalah merintis lisensi dari Badan 
Nasional Sertifikasi Profesi (BNSP) sebagai lembaga yang mendapatkan mandat dari negara untuk melakukan sertifikasi terhadap profesi-profesi yang ada di Indonesia. Lisensi dari BNSP untuk melakukan sertifikasi terhadap pekerja sosial di Indonesia ini dipandang penting untuk memperkuat pengakuan dan penerimaan terhadap sertifikat yang diterbitkan oleh LSPS. Dengan memperoleh lisensi dari BNSP, kualifikasi sebagai pekerja sosial yang kompeten tidak hanya diakui oleh komunitas pekerja sosial, namun juga diakui oleh negara.

Selain itu, hal lain yang sangat startegis untuk dilakukan adalah penyelenggaraan pendidikan profesi, yang diselenggarakan setelah pendidikan sarjana. Hal ini sejalan hakekat sertifikasi profesi pekerjaan sebagai profesi yang dihasilkan dari proses pendidikan. Dengan diselenggarakannya pendidikan profesi, maka proses sertifikasi akan terintegrasi dengan proses pendidikan, sehingga kualitas lulusan pendidikan pekerjaan sosial akan lebih terjamin kualitasm karena setiap sekolah penyelanggara pendidikan profesi akan berusaha menjaga kualitas pendidikannya.

Komponen penting dalam praktik pekerjaan sosial adalah kewenangan bagi pekerja sosial untuk menjalankan profesinya. Pemberian kewenangan kepada pekerja sosial membutuhkan regulasi yang cukup kuat setingkat undang-undang. Regulasi tersebut dapat mengatur praktik pekerjaan sosial beserta aspek-aspek yang terkait dengan aktivitas praktik seorang pekerja sosial.

\section{J. Bahan Bacaan}

DuBois, Brenda L. and Karla Krogsrud Miley. 1992. Social Work: an Empowering Profession. Allyn and Bacon

Hakim, Budi Rahman. 2010. Rethingking Social Work Indonesia. Jakarta : RMBOOKS

Marshall, Edward M. 1995. Transforming The Way We Work: The Power of The Collaboratif Workplace. New York : American Management Association Meyer, H. Carol and Mark A. Mattaini (Editors). 1995. The Foundation of Social Work Practice. NASW Press

\section{$\underline{\text { Artikel Web }}$}

Dorita Setiawan. 2010. Isu Pendidikan Pekerjaan Sosial. melalui <http://www.socialworkers.or.id/index .php?option=com_content $\&$ view $=$ artic le\&id=10\%3Aisu-pendidikanprofesi\&catid=2\%3Aartikel$\underline{\text { umum\&Itemid }=6>}>$ [17/09/2010])

Taufik Winarno. 2010. Membumikan Pekerjaan Sosial. Melalui < http://taufiqchips. wordpress.com/category/sosial// > [15/09/2010]

\section{$\underline{\text { Peraturan-peraturan }}$}


Peraturan Menteri Sosial Republik Indonesia

Nomor 108/HUK/2009 Tentang

Sertifikasi Bagi Pekerja Sosial

Profesional Dan Tenaga Kesejahteraan

Sosial

Peraturan Menteri Sosial Republik Indonesia

Nomor 16/HUK/2012 Tentang
Sertifikasi Pekerja Sosial Profesional

Dan Tenaga Kesejahteraan Sosial

Peraturan Menteri Sosial Republik Indonesia

Nomor 03 Tahun 2015 Tentang

Sertifikasi Pekerja Sosial Profesional

Undang-undang No 11 Tahun 2009 Tentang

Kesejahteraan Sosial 